\title{
A imprensa e o gênero jornalismo do mato no regime militar ${ }^{1}$
}

\section{The press and the bush journalism genre in military regime}

\section{Álvaro Nunes Larangeira}

Docente do Programa de Pós-graduação em Comunicação e Linguagens da Universidade Tuiuti do Paraná. Doutor em Comunicação pela PUCRS e pós-doutor em Jornalismo pela Universidade de Coimbra. <larangeira@terra.com.br>

\section{RESUMO}

O presente artigo propõe-se a conceituar como jornalismo do mato o gênero midiático abonador do período autoritário e distintivo da dubiedade da imprensa em representar-se como baluarte democrático da sociedade. Ela, no entanto, desempenhava, na verdade, o ofício de assessor, cúmplice e publicista de um governo autocrático, repressivo e segregacionista. A análise parte da postura das empresas jornalísticas nos episódios resultantes no golpe de Estado, destituindo João Goulart da presidência da República, em 1964; na validação do regime militar, cuja vigência estendeuse por 21 anos; e retomando a posição majoritária dos jornais no Império de ratificadores na quase totalidade da existência do sistema escravista brasileiro.

Palavras-chave: Jornalismo do mato. Gênero jornalístico. Regime militar.

\section{Introdução}

Em representações contemporâneas a imprensa tem-se apresentado como a condutora do facho das liberdades individuais e coletivas e farol do espírito democrático. Acompanha, a uma distância segura da contaminação, o curso do poder, para recolocá-lo no fluxo da lisura moral e equidade social. Encarna Diógenes de Sinope a conduzir a lanterna à luz do dia, procurando pela honestidade nos seres humanos e a verdade encobertada pelo embuste. Tende,

1 Pesquisa desenvolvida com apoio financeiro do Conselho Nacional de Desenvolvimento Científico e Tecnológico (CNPq) por meio da chamada MCTI/CNPq/MEC/CAPES no 18/2012 - Ciências Humanas, Sociais e Sociais Aplicadas. Trabalho apresentado no GT de História do Jornalismo, no $10^{\circ}$ Encontro Nacional de História da Mídia/Rede Alcar 2015, evento da Associação Brasileira de Pesquisadores de História da Mídia. 
interiorizando concepções auferidas a ela no século XIX, a ser considerada a extensão da voz crítica e o marco divisório da inserção da humanidade no mundo moderno². É a página dojornal, na leitura inspirada de Marshall McLuhan, a expressão confessional comunitária indutora à ação coletiva. Essa é a visão idílica e panglossiana evocada pelo fabulário midiático.

A outra, para delinearmos a intencional perspectiva binária, inserta a imprensa no rol das instituições representativas dos aparelhos privados de hegemonia sobre a sociedade, como faz Antonio Gramsci, ou dos aparelhos ideológicos do Estado, conforme interpretação de Louis Althusser. A imprensa, na análise gramsciana, é elemento vivaz da estrutura ideológica do estrato dominante e, para Althusser, ao fazer parte, com os demais meios de comunicação, dos aparelhos ideológicos da informação, é, em conjunto com a cultura, família, Igreja e sistemas escolar, jurídico, político e sindical, o revérbero material e simbólico dos valores e modos de produção da classe dominante.

O presente artigo propõe-se, a partir da postura das empresas jornalísticas nos episódios resultantes no golpe de Estado destituindo João Goulart da presidência da República em 1964 e na validação do regime militar cuja vigência estendeu-se por 21 anos, e retomando a posição majoritária dos jornais no Império de ratificadores na quase totalidade da existência do sistema escravista brasileiro, a conceituar como jornalismo do mato o gênero midiático abonador do período autoritário e distintivo da dubiedade da imprensa em representarse como baluarte democrático da sociedade, enquanto desempenhava, na verdade, o ofício de assessor, cúmplice e publicista de um governo autocrático, repressivo e segregacionista.

\section{A função capitão do mato}

Ao denunciar na Câmara dos Deputados, em 1887, desvio de função no Exército brasileiro, com soldados a mando do oficialato caçarem escravos fugidos, Joaquim Nabuco asseveraria, indagando: "Há profissão mais alta e mais honrosa do que a profissão de soldado? Há profissão mais baixa e degradante do que a de capitão do mato?" (1949, p. 291). O parlamentar abolicionista associava a função de caçar pessoas ao ataque das aves de rapina às carcaças deixadas pelos predadores. Afora a abjeção à tarefa em si, havia o agravante de ser o capitão do mato, na maioria, negro ou mulato. Em 66 pedidos entre 1827 e 1829 a 26 câmaras municipais fluminenses para o exercício da captura a evadidos,

2 Ver o verbete Presse na Encyclopédie des gens du monde, répertoire universel des sciences, des lettres et des arts, p. 147, Tomo 20, 1844. Disponível em: <http://gallica.bnf.fr/ark:/12148/bpt6k215562c/ f147.highres>. Acesso em 12 de maio de 2015. 
norma estabelecida pelo Aviso Régio emitido pela Secretaria de Estado dos Negócios Estrangeiros e da Guerra, 19 candidatos foram caracterizados como negros, 16 pardos, um branco, um índio e 29 sem especificação da cor. ${ }^{3}$

Alipio Goulart invoca a condição de traidores da raça e pusilânimes a libertos e negros livres empenhados "no perseguir e aprisionar irmãos de sangue, ex-companheiros de infortúnio", lista situações lucrativas da atividade, como recompensas oferecidas pelos senhores de escravo, propinas subtraídas dos afeiçoados aos fugitivos, favores sexuais cobrados das esposas e mães dos prófugos e revenda do capturado a terceiros em caso do valor empenhado for inferior ao preço ofertado por um novo proprietário, além da intrínseca desconfiança com o ofício: "É que, negro ou mulato, embora liberto, o senhor somente vê sob a pressão social do regime: foi escravo tem que persistir escravo" (1972, p. 69 a 71$).$

Arbustos extensos dependem da solidez do tronco para sustentá-los. Entre 1741 e 1760 foram empregadas expedições para dizimar em Minas Gerais o aglomerado quilombola do Campo Grande, onde residiam 15 mil negros fugidos e alguns brancos pobres em 27 quilombos. Para tornar o empreendimento atraente a capitães do mato e soldados, o governo da capitania das Minas Gerais estipulou 32 oitavas de ouro por escravo devolvido, 20 oitavas por alforriado e 6 por cabeça ou par de orelhas do negro morto no assalto aos quilombos (Martins, 2008, p. 869). Tal procedimento seria normatizado. Em andanças pela capital da colônia e naquela época do império português, em 1819, o capitão da cavalaria prussiana Theodor von Leithold narraria a ação dos capitães do mato no Rio de Janeiro e cercanias, a ele relatada:

\footnotetext{
Os capitães andam armados, mas só empregam essas armas se encontram resistência. Aos negros mortos em escaramuças com a polícia cortam-Ihes as cabeças. Entregues estas à Justiça, são elas espetadas em paus e colocadas nas esquinas das ruas principais como advertência (Leithold; Rango, 1966, p. 44).
}

A figura do capitão do mato fazia parte do denominado por Alipio Goulart complexo do escravo fugido, estrutura fundamentada por instâncias legais Livro V, título LXII: Dos coutos ordenados para se coutarem os hominiziados, e dos casos em que Ihe devem valer, e Livro V, título LXIII: Dos que dão ajuda aos escravos cativos para fugirem ou os encobrem, das Ordenações Filipinas ou Código Filipino, promulgadas em 1603 pelo rei de Portugal Felipe I e em vigência até

3 Escravos fugidos, códice 360, Arquivo Nacional. In: BALDO, 1980, p. 104 a 108. 
1830 -, regimentais - Ordem que se passou ao capitao do matto João Pires Pereira para fazer entradas, ${ }^{4}$ assinada pelo governador-geral Alexandre de Sousa Freire, em 18 de outubro de 1667; Patente de capitão do campo dos districtos do Rio Real, na pessoa de Salvador Dias, ${ }^{5}$ assinada por João Rodrigues de Vasconcellos e Souza, Conde de Castel-Melhor, do Conselho de Guerra, em $1^{\circ}$ de abril de 1650; Regimento dos capitães-do-mato baixado por D. Lourenço de Almeida, governador de Minas gerais, a 17 de dezembro de 1722 (Goulart, 1972, p. 286) - e instrumentais, com criações dos cargos de capitão do mato e congêneres capitão de assalto, capitão de campo - e as companhias de guardas campestres, companhias de guardas pedestres e companhias de guardas terrestres. Com a chegada da corte portuguesa em 1808, e toda a administração real para fugir da invasão napoleônica a Portugal, integra-se ao complexo do escravo fugido uma quarta instância: a comunicacional, representada pela imprensa. Candido Neves, personagem do escritor Machado de Assis no conto Pae contra mãe, para exercer sua nova função, capitão do mato urbano, "lia os annuncios, copiava-os, mettia-os no bolso e saía ás pesquizas" (Assis, 1906, p. 9).

\section{A imprensa capitã do mato da sociedade escravagista}

O sociólogo Gilberto Freyre catalogou até a assinatura da Lei Áurea 10 mil anúncios sobre escravos no Diário de Pernambuco, desde 1825, e no carioca Jornal do Commercio, 1827, ressaltando o significado do material para a composição historiográfica e antroporracial dos negros africanos importados e traficados para o Brasil. Baseava-se nos detalhamentos dos tipos físicos dos escravos procurados e ofertados e nas especificações culturais e linguísticas por meio das origens e características tribais anunciadas. Havia ainda na matéria coletada escopo para identificar, pelo estilo redacional dos textos, a expressão literária e sintática média, cotidiana, em contraponto ao empolado linguajar predominante nos artigos jornalísticos. Os anúncios expressavam-se, depurara Freyre, em "linguagem de fotografia de gabinete policial de identificação: minuciosa e até brutal nas minúcias. Sem retoques nem panos mornos" (1979, p. 26). Acrescentaríamos, sem delongas ou contornos: os anúncios naturalizavam os mecanismos de caça, compra e venda de seres humanos e esteavam a até aquela época excrescência-mor do obscurantismo humano, a escravidão.

O assujeitamento da imprensa ao sistema escravocrata deu-se desde os primeiros três meses de vida. Assentada a estrutura administrativa no Rio de

4 Biblioteca Nacional, Documentos Históricos, vol. VIII, 1929, p. 329.

5 Biblioteca Nacional, Documentos Históricos, vol. XXXI, 1936, p. 53 e 54. 
Janeiro, em maio é instituída a Impressão Régia e em 10 de setembro de 1808 lançado pela repartição real a Gazeta do Rio de Janeiro, primeiro jornal editado no Brasil. Em 9 de janeiro e 24 e 25 de fevereiro do ano seguinte despontariam nas respectivas edições os pioneiros anúncios para captura a escravos trânsfugas. Os evadidos eram o escravo Matheus, caracterizado por dois talhos, um nas costas e outro na sobrancelha, o adolescente angolano Matheus, 15 anos, ainda sem conhecimento da língua portuguesa porque adquirido havia pouco tempo no Cais do Valongo, porto da chegada dos navios negreiros e centro do mercado escravagista no Rio de Janeiro, e a mulata Dina, 25 anos, originária da região do Cabo da Boa Esperança, na África do Sul, e fluente em português e inglês. Durante 1809 o periódico, editado por oficiais da Secretaria dos Negócios Estrangeiros e da Guerra e lançado às quartas e sábado, publicaria outros 22 anúncios do gênero.

Os comunicados, ainda esparsos e comedidos em publicações oficiais, caso da Gazeta do Rio de Janeiro, ou particulares com a autorização regencial, como a Idade d'Ouro do Brazil, lançada em Salvador em 1811, multiplicam-se com a revogação em 1821 da exigência do consentimento real para a circulação dos periódicos. O noticioso Diário do Rio de Janeiro, "realmente o primeiro jornal informativo a circular no Brasil" (Sodré, 1999, p. 50) e "no qual gratuitamente se imprimão todos e quaesquer annuncios ou noticias particulares (que convenhão e seja licito imprimir) inclusive os dos divertimentos e dos expectaculos publicos $^{\prime \prime}$, nos 27 exemplares iniciais, correspondente a um mês, publicou 66 avisos com recompensas pela devolução dos negros fugitivos, outros $56 \mathrm{com}$ escravos à venda, 16 para aluguel, a maioria oferecendo ou requisitando amas de leite, e dois para compra e posterior revenda. O redator, reiteradas vezes, orgulhava-se dalgum anúncio resultar na captura, compartilhando o fato sob o título Notícias Particulares: “Tristao de Sá Cherem, faz publico que em o dia 4 de junho, recebeo da D. Anna de Castro, a sua escrava que a mesma sra. havia mandado annunciar neste diario $n^{\circ} 1$ [...] e para sua descarga se faz o prezente annuncio"."

Insatisfeitos em apenas incrementar o comércio escravista, os jornais prestavam-se a ameaçar, intimidar e delatar quem se dispusesse a acolher ou acobertar fugitivos. Anúncios invocavam os amparos legais, o citado título LVIII do Livro V das Ordenações Filipinas - "e quanto aos que derem azo, ou encobrirem, ou ajudarem os captivos fugirem, incorrerão nas penas

6 "Plano para o estabelecimento de hum util e curiozo diario nesta cidade", Diário do Rio de Janeiro, n. 1, 1 jun. 1821.

7 Diário do Rio de Janeiro, 9 jun. 1821, p. 3. 
sobreditas" -, e provisões municipais e provinciais para intimar quem acoutasse ou consentisse com a presença de escravos fugidos na casa ou propriedade. "Fugio hum escravo por nome Manoel, de Nação Moçambique, com os signaes seguintes [...] o annunciante tem noticia que o mesmo escravo esta accoitado em huma casa nesta cidade, por enquanto se faz o prezente annuncio, para a todo o tempo senão chamar a ignorancia, e ficar sugeito ao que a ley determina; quem o conduzir a rua do Rosario n. 92, 20 andar, será bem recompençado", alertava o Diário do Rio de Janeiro, na edição do dia 6 de março de 1826.
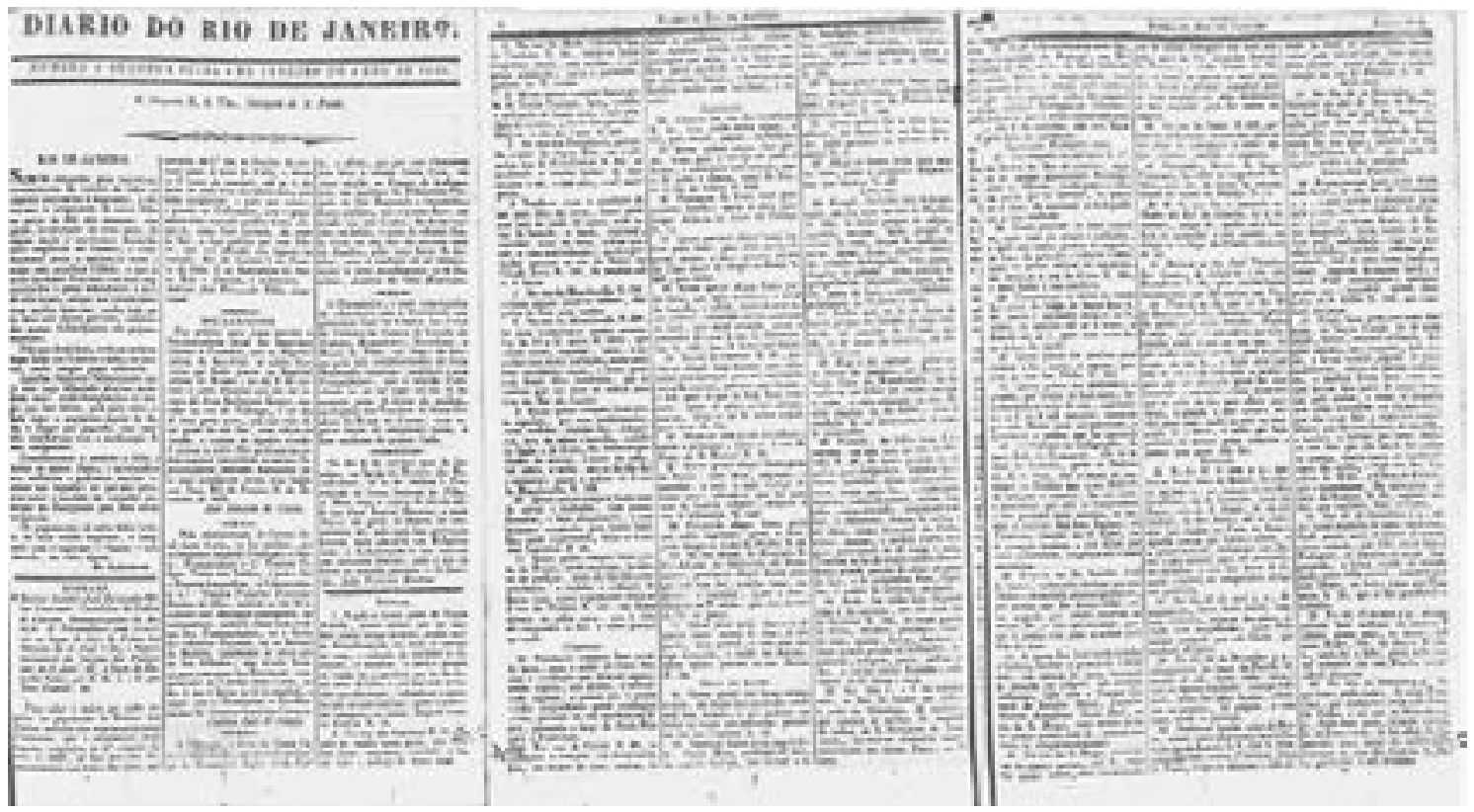

Fig. 1 - Diário do Rio de Janeiro, 4 jan. 1830: venda, compra, aluguel, leilão e caça a escravos.

Fonte: Hemeroteca Digital da Fundação Biblioteca Nacional.

Restringir a ação do complexo do escravo fugido à imprensa correligionária do regime monárquico escravista seria ingenuidade. A conivência com o sistema da exploração do trabalho escravo estendia-se a searas distintas. O periódico gaúcho O Povo, porta-voz do movimento farroupilha e intitulado Jornal Político, Litterario, e Ministerial da Republica Rio-Grandense, tendo por epígrafe "O poder que dirige a revolução, tem que preparar os ânimos dos cidadãos aos sentimentos de fraternidade, de modestia, de igualdade e desinteressado e ardente amor da Pátria" e o lema Liberdade, Igualdade e Humanidade estampados na capa, acolhia anúncios para captura de escravos, nos moldes das publicações monarquistas, com os traços particulares - "com uma bicha na orelha e huma sicatriz na cabeça"; "beiços pintados tem huma sicatriz na 
extremidade da garganta procedida de hum ferimento, por elle praticado em acçao de querer suicidar-se" ${ }^{\prime \prime}$-, para facilitar o reconhecimento do fugitivo, e as devidas gratificações financeiras.

O flagelo do espírito capitão do mato jornalístico atingia também as hostes abolicionistas. Em um único dia, em 1880, a Gazeta de Notícias, propulsora da campanha pelo fim da escravidão, impressora das intervenções de Joaquim Nabuco na Câmara dos Deputados e com José do Patrocínio como colunista, com o pseudônimo anarquista Proudhomme, publicaria seis anúncios da cata a escravos, nos quais, em dois deles, constaria a assertiva inquisitória do "protesta-se com todo o rigor da lei contra quem lhe der couto". O disparate motivou resolução conjunta do movimento. Em junho de 1881 o mensário O Abolicionista, da Sociedade Brasileira Contra a Escravidão e dirigido por Joaquim Nabuco, notificava a determinação encetada pelos abolicionistas: "Levantou-se ultimamente na imprensa abolicionista uma cruzada contra os torpes annuncios de fuga de escravos. [...] Tudo isso é profundamente immoral e depõe seriamente contra a nossa civilisação. Além d'isso, metade d'esses annuncios são criminosos. A policia devia intervir: não para perseguir o escravo fugido, mas para pedir informações ao senhor annunciante".

A medida foi efetivada somente entre os pares, porque na imprensa em geral seria ignorada. O diário católico maranhense $O$ Paiz, a nove dias do 13 de maio de 1888, veiculava a necessidade de "alugar uma negrinha ou um moleque de 10 a 12 anos, mais ou menos, que tenha bons costumes para o serviço domestico". Na semana seguinte à assinatura da Lei Áurea termos do mesmo anúncio seriam atualizados aos novos tempos, trocando o "negrinha" por "rapariga", porém esquecendo de reciclar o verbo alugar.

O concorrente Diário do Maranhão, jornal do Comércio, Lavoura e Indústria, no dia seguinte à abolição da escravatura no Brasil, no editorial Elemento Servil - Abolição, louvaria o ato da princesa imperial regente, D. Isabel, e exclamaria: "Reina no Maranhão verdadeiro prazer, e disso são eloquente prova as manifestações, expansão do sentimento, e isso corrobora tudo quanto se tem dito, que esta província é e sempre foi amante da liberdade, foi a primeira a proclama-la, foi a primeira a cuidar da emancipação, e preparar o espirito para o grande acontecimento que nivela o nosso paiz aos mais cultos da Europa".10 Duas páginas adiante, na mesma edição, o jornal ofertava, para alugar, "uma

8 Edição do dia 27 nov. 1839 , p. 4.

9 Gazeta de Notícias, 19 jan. 1880, p. 3 e 4.

10 Diário do Maranhão, 14 maio 1888, capa. 
mulatinha de 14 anos de idade própria para todo o serviço domestico".11 Assim, consideradas as honrosas exceções, a imprensa, do princípio ao fim do Império, promoveria a nódoa da mentalidade escravagista.

\section{Alugi:se}

umo mulatinha de if annos do idade propria para todo o rervigo donerlice; e alugn-se Ianitiem o 1." oudat da carn $n$. $X$ na rua des Barbrifos proviena as. Largo do Carmo, com muitos coanoo. dos.

A Iratarse no 2." andar da mesma.

Fig. 2 - Diário do Maranhão, 14 maio 1888: Aluga-se mulatinha.

Fonte: Hemeroteca Digital da Fundação Biblioteca Nacional.

\section{O jornalismo do mato da imprensa brasileira no regime militar}

O incubado instinto de caça da imprensa brasileira afloraria na plenitude já no segundo dia do golpe militar civil-midiático de 1964. O Jornal, principal publicação impressa do grupo midiático hegemônico na época, os Diários Associados, formado por 30 diários, três revistas, uma agência de notícias, 25 rádios e $70 \%$ das emissoras de televisão - a ponto do slogan ser"Onde houver um receptor de TV, há sempre presente a imagem de um canal Associado" (Morais, 1994, p. 633) -, cobraria dos militares protagonistas da derrubada do governo constitucional do trabalhista João Goulart uma imediata operação-limpeza, compreendendo "a higienização da vida pública brasileira" por intermédio da intervenção em centrais sindicais e movimento estudantil, exoneração em estatais, supressão dos direitos políticos a parlamentares alcunhados comunistas e enquadramento na Lei de Segurança Nacional a civis e militares associados ao governo deposto. ${ }^{12}$

A nominata dos candidatos a expurgos e outras providências coercitivas seria apresentada pela Tribuna da Imprensa, do jornalista Hélio Fernandes, contemplado com a cassação dos direitos políticos por 10 anos pelo Ato Institucional no 1 em 1966, no primeiro governo militar, e degredado por meses

11 Diário do Maranhão, 14 maio 1888, p. 3.

12 “Operação-limpeza”, O Jornal, 2 abr. 1964, p. 1. 
na Ilha Fernando de Noronha em 1967, no segundo governo do regime militar. $O$ editorial "Pela recuperação do Brasil ${ }^{\prime 13}$ rogava aos novos mandantes providências contra o presidente, ministros civis e militares, deputados, sindicalistas, líderes estudantis e diretores de estatais. "Não se trata de vingança, nem estamos aqui defendendo o esquartejamento dos derrotados. Mas quando o destino do país está em jôgo, quando se trata de decidir a sorte dos que queriam comunizar o país, não podemos ser generosos ou sentimentais", justificava o jornal, com argumento similar ao dos senhores na aplicação do suplício a escravos fugidos, insolentes ou aquilombados.

Seria por demais prejudicial à imagem liberal e democrática da imprensa publicar índices autorais extensos. Então, as publicações recorreriam a subterfúgios sutis. Em 7 de abril os exemplares da Tribuna da Imprensa e O Globo continhama republicação do anúncioveiculadoem outubro de 1963 dafundação do Comando dos Trabalhadores Intelectuais, com os nomes dos 13 diretores e 214 signatários das áreas do direito, arquitetura, literatura, ciência, música, teatro, artes plásticas, educação, mercado editorial, cinema, rádio e televisão, jornalismo e economia. A estratégia de tornar apócrifa a delatória "transcrição paga por um grupo de democratas" passaria incólume se despercebida ficasse a mão editorial no cabeçalho do anúncio. "Este é o manifesto do chamado Comando dos Trabalhadores Intelectuais, que trabalhou ativamente pela implantação do governo comunista do sr. João Goulart. Republicando-o com todos os seus nomes, chamamos a atenção do alto-comando militar", era o da Tribuna; 14 "Este é o manifesto do chamado Comando dos Trabalhadores Intelectuais, que trabalhou ativamente pela implantação do regime comunista no Brasil. Republicando-o agora, chamamos a atenção do alto-comando militar para os nomes que o assinaram", seria o do O Globo. ${ }^{15}$

13 Tribuna da Imprensa, 2 abr. 1964, p. 1.

14 Tribuna da Imprensa, 7 abr. 1964, p. 3.

15 O Globo, 7 abr. 1964, p. 5. 


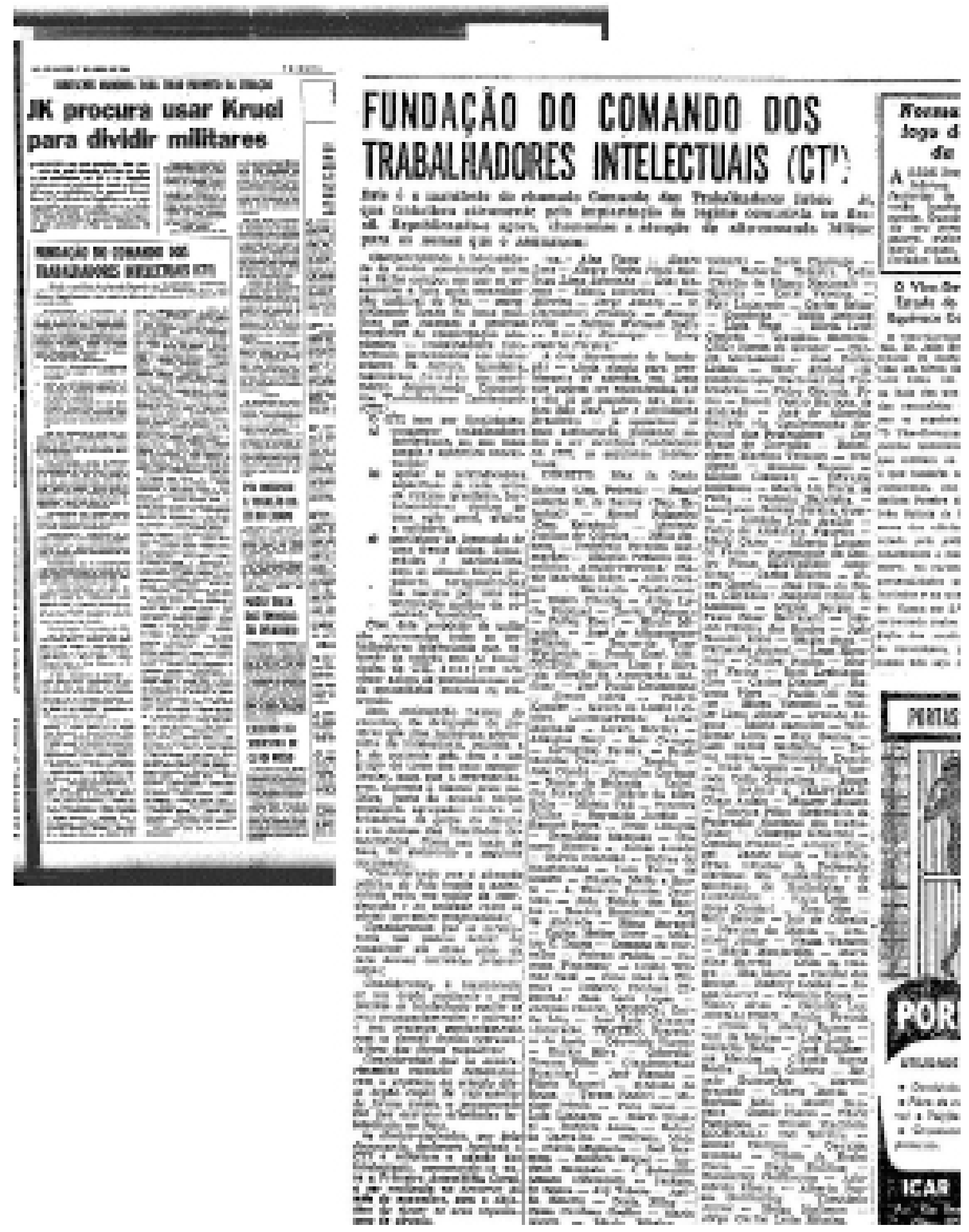

Fig. 3 - Anúncios em O Globo e Tribuna da Imprensa disfarçados como A pedido para delatar 214 intelectuais simpatizantes do governo deposto.

Fonte: Acervo O Globo e Setor de Periódicos da Biblioteca Nacional. 
Haveria perseguições personalizadas. A presença da historiadora catedrática em História Moderna e Contemporânea, representante da Universidade do Brasil no Instituto Brasileiro de Estudos Afro-Asiáticos e diretora da rádio do Ministério da Educação e Cultura, nomeada em julho de 1963 e desonerada extra-oficialmente na tarde do $1^{\circ}$ de abril de 1964, Maria Yedda Leite Linhares, no gabinete do reitor da universidade motivou a chamada "O reitor recebe a comunista" na capa do O Globo. ${ }^{16}$ A matéria incluía a docente no grupo a serviço do comunismo internacional e, para lamento do jornal, ainda à solta: “Estamos certos que o seu tranquilo reaparecimento - no guichê do Ministério e no gabinete do Reitor - alertará lembranças esquecidas e concitará a adoção de medidas necessárias e urgentes". Maria Linhares seria inquirida em 1964 pela Comissão de Investigações da Universidade do Brasil, presidida por um general, arrolada em sete inquéritos policiais militares entre 1964 e 1966 e em abril de 1969 agraciada com a aposentadoria compulsória pelo Ato Institucional nº 5.

16 O Globo, 9 maio 1964, p. 1. 


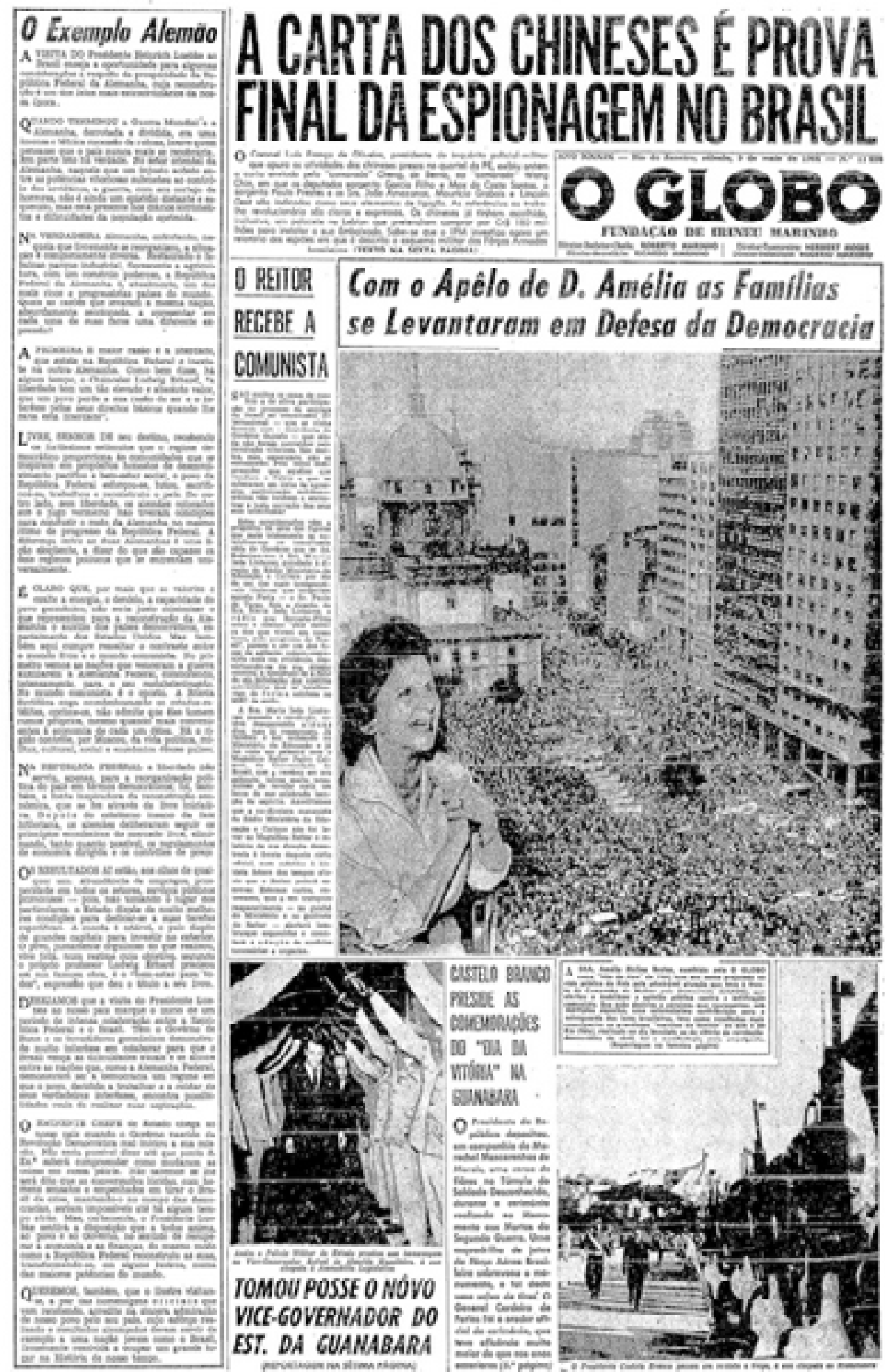

Fig. 4 - Jornal O Globo pede providências contra professora da Universidade do Brasil.

Fonte: Acervo O Globo. 
A imprensa tornar-se-ia mural dos perseguidos pelo regime militar, a exemplo das seções de anúncios nos tempos finais do Brasil colônia e todo o Império, e copista das versões falsas do Estado militar para escamotear e legalizar crimes computados aos aparatos repressivos oficial e clandestino, costume senhorial de dar por fugido quem haviam assassinado. No cartaz "Terroristas procurados: ajude a proteger sua família e a de seus familiares: avise a polícia" e na lista dos principais terroristas procurados no Brasil, entregues pelos "órgãos de segurança" aos jornais e cujo material rendeu à Folha de S. Paulo matérias por quatro dias - 28 de setembro a $1^{\circ}$ de outubro de 1971 - havia o nome do militante do Movimento Revolucionário 8 de Outubro (MR-8) Stuart Edgar Angel Jones, preso por agentes do Centro de Informações de Segurança da Aeronáutica (CISA) e morto na Base Aérea do Galeão em julho do mesmo ano, portanto antes da confecção dos cartazes.

Dos 40 listados no documento reprisado por Folha de S. Paulo, Estado de S. Paulo e $O$ Globo, três outros procurados - os dirigentes da Vanguarda Armada Revolucionária Palmares (VAR-Palmares) Carlos Alberto Soares de Freitas, detido no Recife em fevereiro de 1971, e Mariano Joaquim da Silva, preso na rodoviária da capital pernambucana em setembro de 1970; e o militante da Ação Libertadora Nacional (ALN) Paulo de Tarso Celestino da Silva, capturado no Rio em julho de $1971^{17}$ - naquela data estavam mortos e, somados a Stuart Jones, constariam no dossiê dos 144 desaparecidos no Brasil, editado em 1984 pela Comissão de Familiares de Mortos e Desaparecidos do Comitê Brasileiro de Anistia (CBA). Em 1971 o governo brasileiro sofria pressão interna, por parte da Conferência Nacional dos Bispos do Brasil (CNBB), e externa, por entidades internacionais dos direitos humanos, para dar explicações às acusações de torturas e desaparecimentos e um dos estratagemas foi inserir presos em situação ilegal, ou já mortos, nessas listas dos procurados enviadas e reproduzidas pela imprensa.

Outra artimanha do governo militar foi encaixar mortos da tortura clandestina institucional nos tiroteios com a guerrilha urbana. Caso típico foi 17 de janeiro de 1973. Jornais publicariam o texto redigido pelo Serviço de Relações Públicas do I Exército da ação policial contra aparelho do Partido Comunista Brasileiro Revolucionário (PCBR) na ex-capital federal, no final do ano anterior. "Bastante nervoso, "Sandália" [Fernando Augusto Valente da Fonseca] dirigiu-se a pé para o volks, sendo recebido a tiros. Em decorrência, as equipes de segurança se aproximaram, travando-se então intenso tiroteio, após o qual o

17 Comissão de familiares de mortos..., 1995, p. 271, 351 e 366. 
fuscão se incendiou. No interior do carro, estavam mortos os terroristas Getúlio de Oliveira Cabral (Gogó), José Bartolomeu Rodrigues de Sousa ("Tropi") e José Silton Pinheiro ("Soares")", descreveria a nota do Exército ${ }^{18}$. Na verdade, Fernando Augusto Valente da Fonseca, Getúlio de Oliveira Cabral, José Bartolomeu de Sousa e José Silton Pinheiro foram mortos na sede carioca do Destacamento de Operações e Informações - Centro de Operações de Defesa Interna (DOI-CODI) e inseridos na cena do crime. $^{19}$

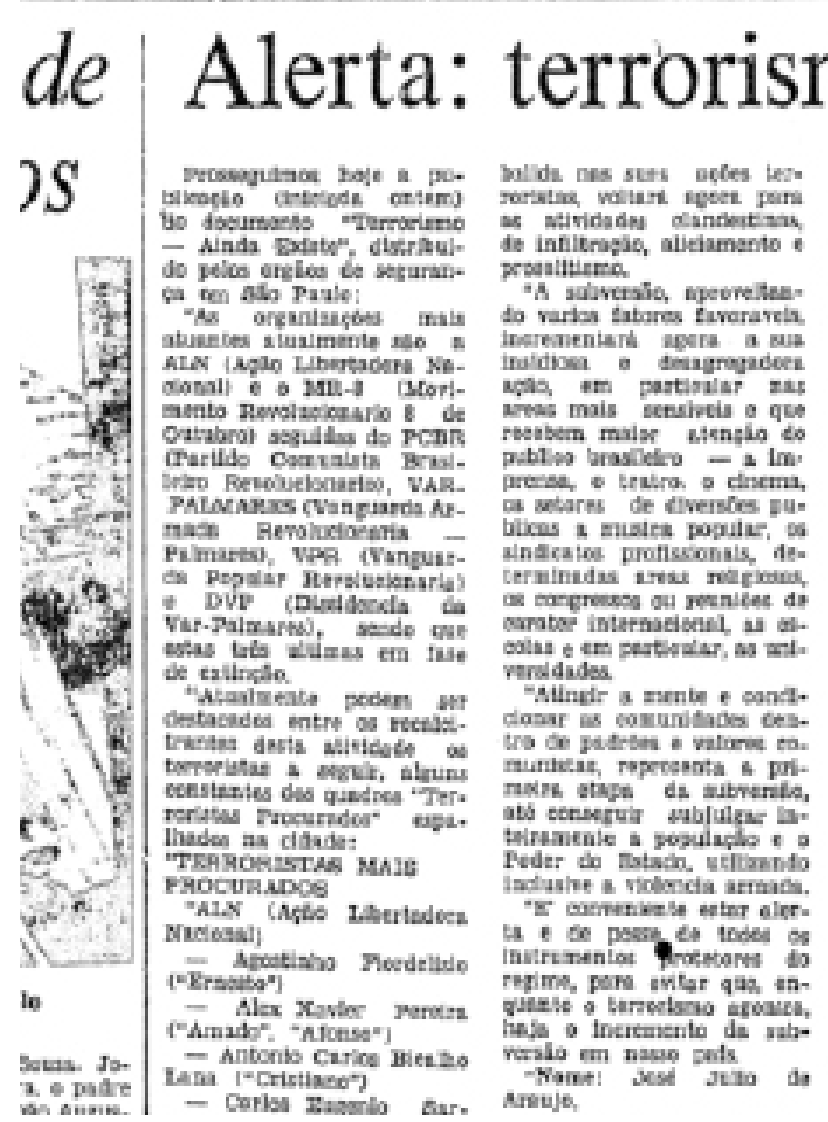

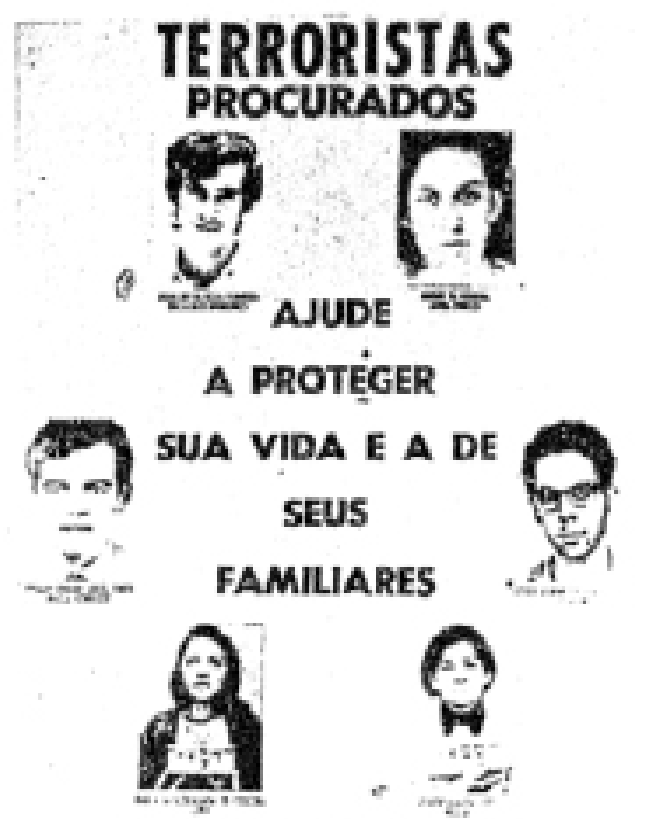

AVISE A POLICIA

Cartazes come este toram espathados pela eldade

Fig. 5: Anúncios de terroristas procurados continham mortos por tortura.

Fonte: Acervo Folha de S. Paulo.

O último exemplo, selecionado por esse estudo, das manifestações do jornalismo do mato ocorreria em 1977. Expoente da extrema-direita, líder dos militares discordantes da distensão política protagonizada pelo governo e

18 Diário de Notícias (RJ), p. 11; Folha de S. Paulo, p. 4; Jornal do Brasil, p. 16.

19 Comissão de familiares de mortos..., 1995, p. 145, 151, 158 e 162. 
candidato do grupo à sucessão do general-presidente Ernesto Geisel, o ministro do Exército Sylvio Frota é exonerado em outubro e em represália ao afastamento acusa haver "complacência criminal com a infiltração comunista e a propaganda esquerdista que se revitaliza diariamente na imprensa, nos setores estudantis e nos próprios organismos governamentais, os quais acolhem, no momento, nos escalões de assessoramento e direção, 97 comunistas militantes, conforme comuniquei ao Serviço Nacional de Informações, marxistas que permanecem intocáveis, em suas atividades desagregadoras". ${ }^{20} \mathrm{O}$ documento passaria a circular pelo Congresso Nacional em novembro, à espera de divulgação.

Pois o Estado de S. Paulo, no dia 24 daquele mês, e o Jornal do Brasil e diversas publicações pelo país, no dia seguinte, postariam o índex dos órgãos de segurança compilado pelo Centro de Informações do II Exército com 96 [um nome constava duas vezes] servidores públicos lotados em ministérios, estatais, fundações e em 10 governos estaduais. O Brasil tomaria conhecimento do histórico dos citados, alguns já falecidos, junto aos sistemas de informação e segurança do regime militar, da existência de 12 potenciais agentes da KGB, serviço secreto da União das Repúblicas Socialistas Soviéticas (URSS), uma acusada de agiotagem, quatro funcionárias amasiadas [termo original] com subversivos e uma desquitada amasiada. $O$ jornalismo do mato, com a inclusão da ficha político-ideológica e estado conjugal, aprimorava dessa forma o anacrônico recurso da indicação das marcas pessoais para auxiliar a atividade persecutória dos capitães do mato, como fazia no século XIX nos anúncios sobre escravos.

20 "A nota do ex-ministro", Jornal do Brasil, 13 out. 1977, p. 4. 


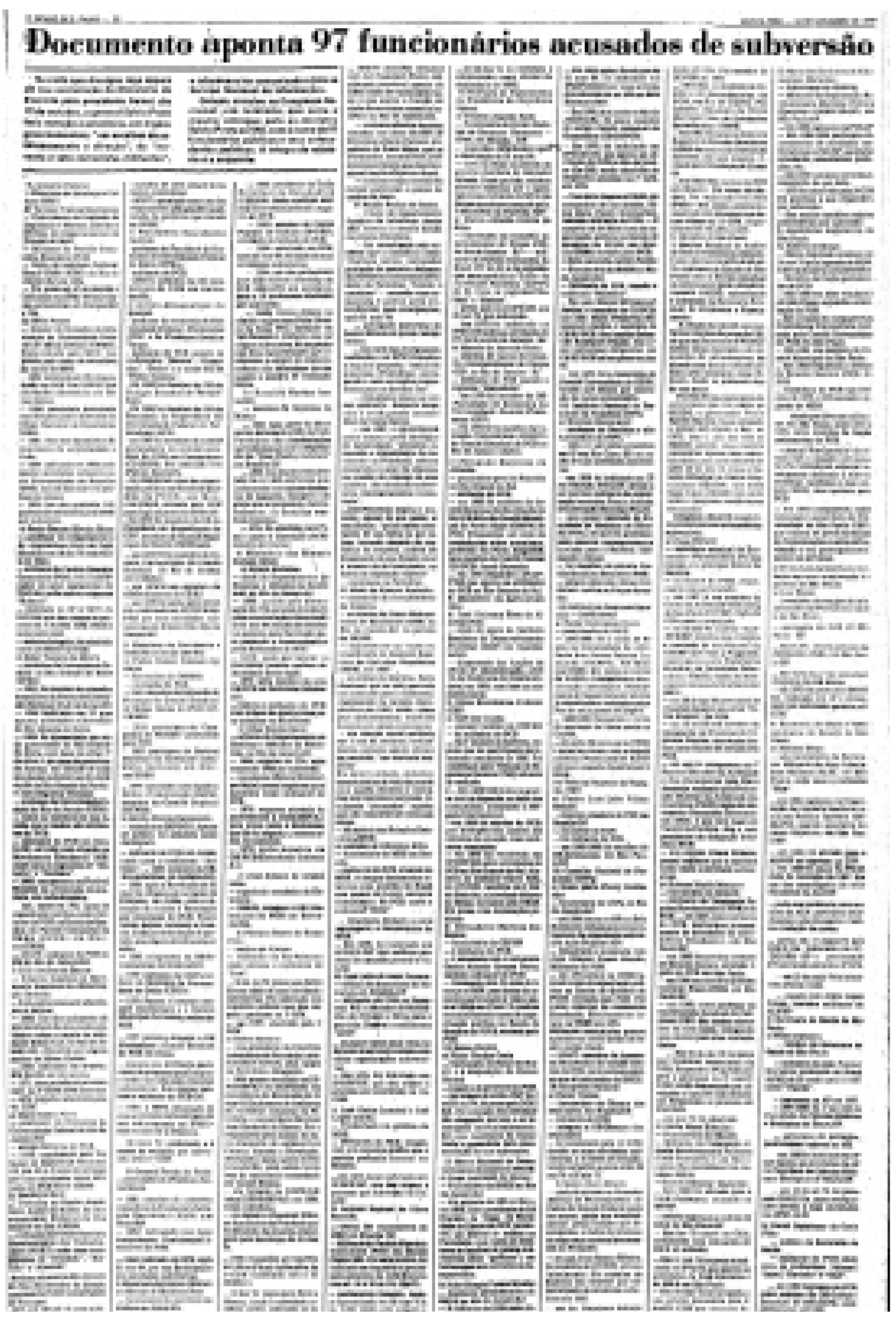

Fig. 6: Lista publicada em 1977 com 96 pessoas consideradas comunistas.

Fonte: Acervo Estado de S. Paulo. 


\section{Considerações finais: o conceito Jornalismo do mato}

Ojornalismo do mato é o gênero jornalístico derivado do enquadramento midiático à superestrutura sistêmica - entendendo a superestrutura como o estamento superior formatado pela instância jurídico-política formadora do Estado e a instância ideológica representada pelas expressões culturais, ideológicas e morais (Althusser, 1985, p. 60) - e caracterizado pelo exercício laboral apendiculado à estrutura repressiva do regime político o qual afiança. Ao se sujeitar às atividades delativas, inquisitoriais e policialescas, o jornalismo do mato desempenha a função superior de legitimador regimental e a inferior de escabelo do descanso do senhorio e feitor do organismo coercitivo estatal. Autentica, dessa maneira, ofundamento reacionário acobertado nos dispositivos semânticos da retórica moralisséptica própria dos regimes ditatoriais, em especial os originados nas casernas.

A fonte do jornalismo do mato, durante o regime militar brasileiro, ao invés do acalantado ditirambo da colheita no mundo da vida, foi o veio freático do imaginário das forças basilares das duas décadas do autoritarismo, externado em versões ministeriais ou dos vazamentos deliberados do organograma gerenciado pelo Serviço Nacional de Informações e abastecido pelo suporte clandestino dos centros de informações das Forças Armadas Centro de Informações do Exército (CIE), Centro de Informações de Segurança da Aeronáutica, Centro de Informações da Marinha (CENIMAR) e os DOI-CODI -e pelas subordinadas polícias federal, civil e militar, principalmente as delegacias de ordem política e social (DOPS).

O jornalismo do mato, nas eventuais aparições no confessionário da História brasileira, sempre silenciou ou se esquivou das responsabilidades como ativista político, social e ideológico, contando com a conivência da imprensa mainstream, fato atestado com o desmemoriamento estratégico perceptível nas efemérides concebidas por ela mesma, como nas retrospectivas dos 50 anos do início do regime militar, publicadas em 2014, e dos 30 anos do ocaso dos governos militares, lançadas em março de 2015. O jornalismo do mato, como seus antepassados do Império, demonstra dificuldades em assumir o caráter retrógrado, sociofóbico e avesso a movimentos progressistas, distributivos e contestatórios, como se os mesmos colocassem em risco a própria sobrevivência. A reação tem natural temor por avançar. O jornalismo do mato, em cruzar adiante com Diógenes, e ter seus feitos iluminados pela lanterna do filósofo grego. 


\section{Referências:}

ACERVO ESTADO DE S. PAULO -Disponível em: <http://www.acervo.estadao.com.br> Acesso em 10 de maio de 2015.

ACERVO FOLHA DE S. PAULO - Disponível em: <http://www.acervo.folha.com.br> Acesso em 10 de maio de 2015.

ACERVO JORNAL DO BRASIL - Disponível em: < http://www.jb.com.br/paginas/newsarchive > Acesso em 30 de abril.

ACERVO O GLOBO - Disponível em: <http://www.acervo.oglobo.com.br> Acesso em 05 de maio de 2015.

ALTHUSSER, Louis. Aparelhos ideológicos de Estado. 2. ed. Rio de Janeiro: Graal, 1985.

ARMAZÉM MEMÓRIA - Disponível em:< http:// www.armazemmemoria.com.br> Acesso em 10 de maio de 2015.

ARQUIDIOCESE DE SÃO PAULO. Brasil: nunca mais. Petrópolis: Vozes, 2011.

ASSIS, Machado de. Pae contra mãe. In: Reliquias de casa velha. Rio de Janeiro: H. Garnier, 1906.

BALDO, Mario. O capitão-do-mato. 1980. 132 f. Dissertação (Mestrado em História do Brasil). Curso de Pós-graduação em História, Universidade Federal do Paraná, Curitiba, 1980.

BIBLIOTECA BRASILIANA GUITA E JOSÉ MINDLIN - Disponível em: < http://www. brasiliana.usp.br> Acesso em 28 de abril de 2015.

BIBLIOTECA NACIONAL. Documentos históricos - 1650-1693: Provisões, patentes, alvarás. Vol. XXXI. Rio de Janeiro: Typographia Archivo de História Brasileira, 1936.

. Documentos Históricos - 1660-1670: Portaria dos governadores geraes Francisco Barreto, Conde de Obidos, Alexandre de Souza Freire. Vol. VIII da Série E V dos DOCS. da Bib. Nac. Rio de Janeiro: Augusto Porto \& E, 1929.

COMISSÃO DE FAMILIARES DE MORTOS E DESAPARECIDOS POLÍTICOS; INSTITUTO DE ESTUDO DA VIOLÊNCIA DO ESTADO; GRUPO TORTURA NUNCA MAIS. Dossiê dos mortos e desaparecidos políticos a partir de 1964. São Paulo: Imprensa Oficial do Estado, 1995.

FREYRE, Gilberto. Os escravos nos anúncios de jornais brasileiros do século XIX. Recife: Imprensa Universitária, 1963.

FUNDAÇÃO BIBLIOTECA NACIONAL - Setor de periódicos: O Dia, O Jornal e Tribuna 
da Imprensa.

GOULART, José Alípio. Da fuga ao suicídio: aspectos da rebeldia dos escravos no Brasil. Temas Brasileiros. Rio de Janeiro: Conquista; Brasília: Instituto Nacional do Livro, 1972.

GRAMSCI, Antonio. Cadernos do cárcere: v. 2: Os intelectuais. O princípio educativo. Jornalismo. 3. ed. Rio de Janeiro: Civilização Brasileira, 2004.

HEMEROTECA DIGITAL BRASILEIRA -Disponível em: <http://hemerotecadigital.

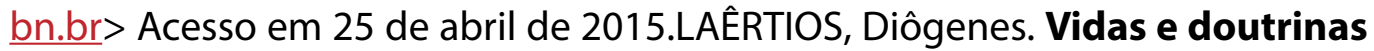
dos filósofos ilustres. 2. ed. Brasília: Editora UnB, 2008.

LEITHOLD, Theodor von; RANGO, Ludwig von. O Rio de Janeiro visto por dois prussianos em 1819. São Paulo: Companhia Editora Nacional, 1966.

MARTINS. Tarcísio José. Quilombo do Campo Grande: A história de Minas que se devolve ao povo. Contagem: Santa Clara, 2008.

MCLUHAN, Marshall. Os meios de comunicação como extensões do homem. São Paulo: Cultrix, 1969.

MORAIS, Fernando. Chatô: o rei do Brasil. São Paulo: Companhia das Letras, 1994.

NABUCO, Joaquim. Discursos parlamentares (1879-1889): obras completas de Joaquim Nabuco. V. 11. São Paulo: Instituto Progresso Editorial, 1949.

SODRÉ. Nelson Werneck. História da imprensa no Brasil. 4. ed. Rio de janeiro: Mauad, 1999.

VOLTAIRE. Cândido ou o Otimismo. Porto Alegre: L\&PM, 2009.

Recebido em: 14/7/2015

Aceito em: 04/8/2015

Endereço do autor

Álvaro Nunes Larangeira<larangeira@terra.com.br>

Universidade Tuiuti do Paraná, Mestrado em Comunicação e Linguagens.

Rua Sydnei Lima Santos, 238 - Santo Inácio

82010-330 - Curitiba, PR - Brasil 